UDC: $37.07: 351.851$

DOI: https://doi.org/10.24195/2414-4665-2017-5-11

\author{
Inna Gryshova, \\ Doctor of Economics, associate professor, \\ Senior researcher of the Institute of Legislation, \\ Verkhovna Rada of Ukraine \\ Nestorivskyi lane, 4, Kyiv, Ukraine, \\ Viktor Zamlynskyi, \\ Doctor of Economics, associate professor, \\ Department of Accounting and Taxation, \\ Odessa Trade and Economic Institute of \\ Kyiv national Trade and Economic University, \\ 7, 25 Chapaivskoi Divisii Str., Odessa, Ukraine, \\ Tetiana Shestakovska, \\ Candidate of Economic Sciences, \\ senior lecturer, Department of Theory of Economics, \\ Chernihiv National University of Technology, \\ Ministry of Education and Science of Ukraine, \\ 1, Striletska Str., Chernihiv, Ukraine
}

\title{
IMPLEMENTING CLUSTER FORMS INTO NATIONAL EDUCATION DEVELOPMENT STRATEGY
}

The paper aims to reveal the peculiarities of educational clusters formation, to determine the theoretical foundations of this process and rationale for the use of the cluster approach in the management of strategic development of the national educational system under modern market conditions. Educational cluster is a set of organizations in various industrial branches, the organizational and legal forms of government and social structures that define and provide the implementation of educational programs of a certain level or focus, and the conditions for strategic innovative development of the system of education in today's market conditions, involving the specific forms of innovation activities that have approved themselves in the process of implementation of large-scale experiments, pilot projects on specific areas of modernization. The education cluster can be a tool of state policy of Ukraine in the field of gaining a leading position in the global markets of education. The formation and development of effective education clusters will contribute to the acceleration of the transfer (exchange) of information and networking; faster response to the changes in the environment; facilitation of the access to new technologies; the sharing of knowledge and assets; acceleration and improvement of the efficiency of staff training through concentration, physical contacts of world class specialists, correction of the curricula, organization of joint programs of training; the reducing of the transaction costs in various areas; the increasing of the investments by achieving sustainable competitive advantages.

Keywords: educational cluster, the management of education, partnership, innovations, the efficiency of cluster, a strategic development of education.

\section{Introduction}

The present conditions in which educational institutions are operating and developing, the integration of Ukraine into the European educational space have caused the intensive development of the national education system. The leading task of educational institutions functioning is creating conditions for personal development of each participant of the educational process and its focusing on comprehension and acquisition of new pedagogical realities, creating new philosophy of education open for the mysteries of person's life, his/her aspirations, and spiritual world. Current trends demonstrate that forming clusters should be considered as an efficient approach to achieving the goals of the education development. Being relatively stable organizational and economic forms, they can present the educational space in a new way, fully identify and realize the benefits of integration of the ob- jectives and resources of different subjects of business activities. These are educational clusters that make the education development multisectoral, create a real interdisciplinary mechanism of management ensuring the quality of education.

The works by A. Anufriev, B. Bazeliuk, T. Borova, A. Halus, I. Drach, L. Kalinin, V. Kamyshin, V. Maslov, V. Oleinik, G. Poliakov, G. Timoshko, V. Yakovets, $\mathrm{V}$. Yakunin are dedicated to the issue of management in the field of education in general and the activities of educational institutions in particular. Various aspects of the development of educational clusters are studied in the works of local and foreign scientists: N. Zakharov, T. Krasikov, N. Korchagina, V. Kutsenko, O. Smirnov, E. Chernyshov and others.

The scientific literature review shows that there is no clear definition of the term "educational cluster", and its 
role in the strategic development of the education system is still understudied. For example, E. Chernyshova considers educational cluster as a network of suppliers, manufacturers and consumers of educational services and technologies, as well as the elements of educational infrastructure, whose activity is based on the positive synergistic effects of educational agglomeration (the network technologies, the integration of knowledge and skills, proximity to a consumer and producer of educational services, etc.) [1].

According to N. Korchahina, educational cluster is a group of educational institutions which are in partnership with the branches of industry located in the same area, and the end product of their activity is education. The core of the cluster in this case is a higher educational institution or other kinds of educational establishments [2]. O. Smirnov considers educational cluster as a system of training, mutual training and learning tools in the innovation chain "science-technology-business", which is based mainly on horizontal relations within the chain. This educational cluster is based on the educational process. Thus, the educational cluster can be regarded from two perspectives: as a system and a process [3].

However, it should be added that the educational cluster is an integral part, a necessary step and means of innovation activity in the part that is responsible for the creation of new educational systems or their individual components. Thus, we understand "educational cluster" as a set of organizations in various industrial branches, the organizational and legal forms of government and social structures that define and ensure the implementation of educational programs of a certain level or focus, and the conditions for strategic innovative development of the system of education in today's market conditions, involving the specific forms of innovation activities that have approved themselves in the process of implementation of large-scale experiments, pilot projects on specific areas of modernization.

The paper aims to study the peculiarities of educational clusters formation, to determine the theoretical foundations of this process and rationale for the use of the cluster approach in the management of strategic development of the national educational system under modern market conditions.

\section{Research methods}

The following research methods were used in the study: scientific literature review, theoretical analysis, comparison, content analysis, a method of selfassessment, observation, specification, etc.

\section{Discussion}

The increasing number of uncompetitive national educational institutions causes the necessity of implementing significant changes in the concept of modern education modernization. Their realization in Ukraine can be carried out only in the innovative environment that involves the implementation of cluster forms in organizing interaction processes in the course of training.
The creation and support of educational clusters primarily involve determining possible composition of their participants, the principles and conditions of their association and interaction, the mechanisms of management providing the education development. Since the process of creating economic clusters is already applied in the economy the principles and mechanisms of clustering developed by the scientists can be taken as a sample and transferred into the education system with the necessary adjustment.

Usually the cluster represents a joint organizational network structure (closed subject) based on a combination of vertical and horizontal integration of legally independent enterprises of various technologically related industries under the leadership of these companies' board members with the participation of regional authorities and the public [4].

In order to form educational clusters, it is urgently important to consider the following features:

1. Different in the form of their ownership, organizational and legal status and membership industries are joined together in the cluster as an integral system of the final product production.

2. The cluster should involve all elements of the technological chain of the process of creating and using the product - from educational services provision to their results implementation. This includes the development of innovations and training personnel as a condition for the development of this market segment.

3. All cluster's members retain their legal and economic independence.

4. The management of the cluster is carried out by a collective body - the Board of representatives of all organizations (production, research, trade, financial, transport and other infrastructure organizations), as well as the representatives of the authorities and the public;

5. Cooperative relationships are established between cluster members to achieve common objectives through joint strategic plans, agreements, sharing the brands and other intangible assets, thereby reducing transaction costs and increasing the capitalization of the brand [5]

If we consider educational clusters as an integral system of final product manufacturing, it is advisable to point out three "final products" in the system of education that differ in the technological chain of their "creation" and "use" - such as, preschoolers, secondary school graduates and vocational school graduates. Despite the obvious ethical inadmissibility of equating a child or an adult with the product in this case it is considered to be a necessity, having in mind that the educated person is the result of educational activity. Based on these three main "types of results" we distinguish the cluster of vocational education, the cluster of general education and the cluster of preschool education.

The intersection of these clusters shows the "transitional" pieces of the continuous education chain within which both clusters solve common educational objectives (preparing young generation for transferring to the next 
level of education) and work together up to the organization of the educational process on the basis of any of the institutions of the corresponding level.

The education cluster is formed on the basis of those socially and organizationally designed structures where the child's development takes place at every period of his/her aging. In Ukraine, the presence of local authorities in regional clusters is a basic condition for achieving success, because we have to talk about social responsibility not only of business, but the authorities as well.

The most important condition for the development of national education cluster is a comprehensive infrastructure that includes a material part (in the form of buildings and facilities suitable for children and educational programs implementation); the infrastructure of well-being (the child nutrition suppliers, the maintenance and repairing of material resources); medical and educational service (speech therapists, psychologists, social workers); innovative infrastructure (resource centers, the centers of excellence, innovation and experimental platforms).
The overall structure of the education cluster includes the following mandatory components: the core of the cluster involving the structures that implement the educational process, necessary infrastructure of the development, the partner organizations and the governments of the cluster (Fig. 1) [4].

A family plays a special role in the education cluster. In addition, at the level of general education a family is both "the educational structure" as the child's education and socialization take place (or do not) in the family; and socio-economic status, general cultural characteristics of each family have more and more impact on learning outcomes. Equally important is the fact that the family budget is a decisive financial source of the development of education. The interaction of the school with students' parents is quite organized in nature and its forms have been developed and worked out for decades. There are new variants to engage parents into school management and development.

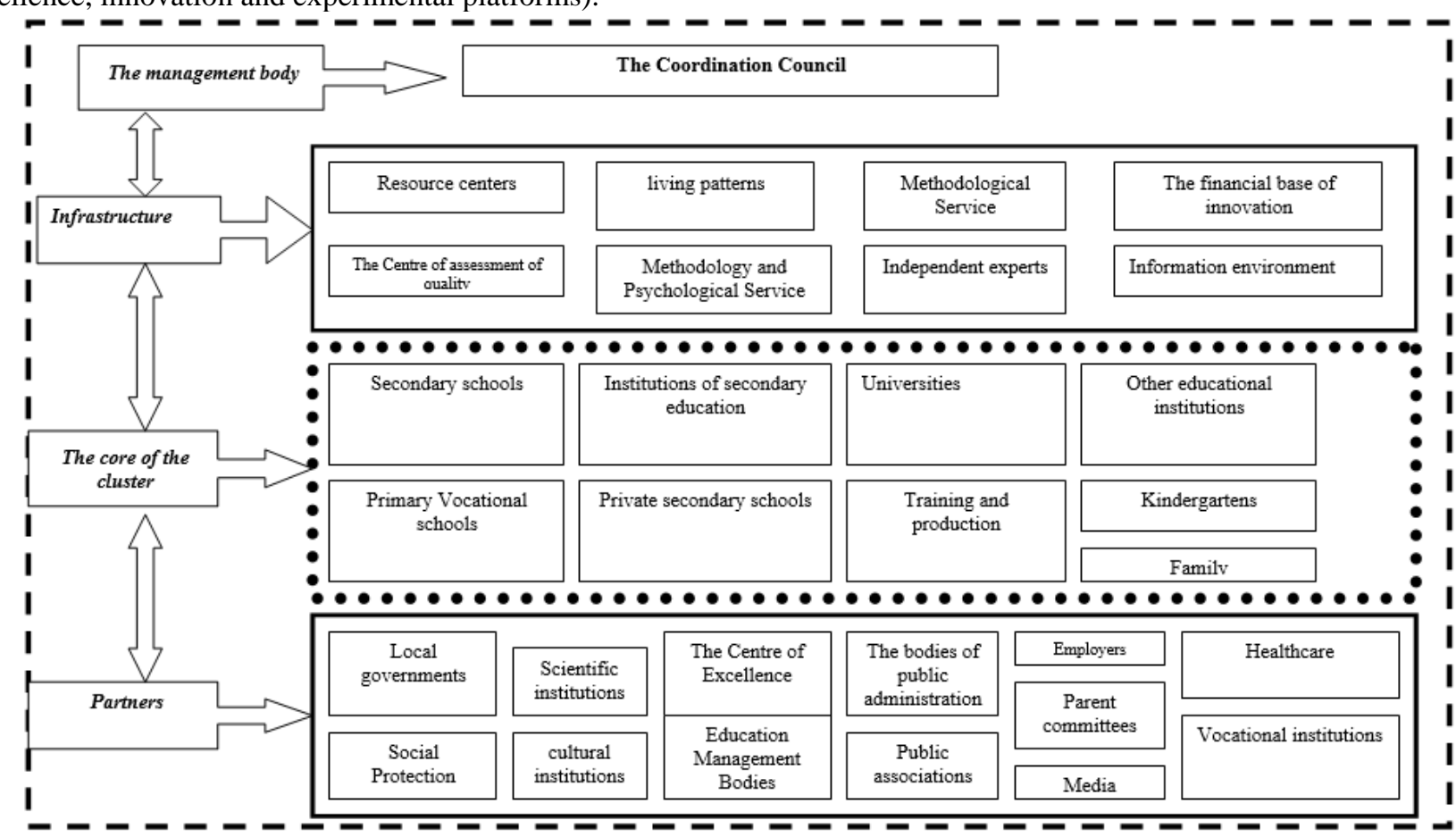

Fig. 1. The functional model of the educational cluster

The infrastructure of the national education development also requires particular attention. The long period of educational system modernization has led to the emergence of specific forms of innovations that have approved themselves in the process of implementation of large-scale experiments, pilot projects on specific areas of modernization. First of all, these are the resource centers, testing centers of education quality as structural elements of the system of assessment of the education quality, experimental platforms, innovation platforms (forums, exhibitions, public presentations) as a space of public presentation of innovations and the distribution of innovative experience, information and instructional services, independent public experts and others.
The phenomenon of "innovation complexes" in education organized and controlled by means of the interaction of research groups and educational communities, educational institutions, educational authorities aiming to improve the quality of education and business competitiveness under market conditions is also a very important issue in the context of this study [6].

The interest of business organizations in participating in educational clusters can be explained by the fact that one of the major constraints of the real sector of economy is the lack of qualified, skilled workers. This implies a potential interest in the educational institutions' programs implemented on the territories of enterprises. 
The participation in the educational clusters should be of interest primarily to small and medium companies that do not have their corporate educational institutions and are guided by the local labor market when hiring the staff. Thus, the employers do not just form the structure of demand for skilled workers and professionals, they should make the requirements for the directions and the quality of training of these professionals taking into account the development of enterprises and preventing the migration of educated population [7].

The main interaction of business and education takes place through the system of vocational training (working for the local labor market) which is focused on secondary education as well (mostly on upper secondary school), forming the orientation at the selected vector of the territory's economic development, as well as the development of the necessary human resources. The impetus for the participation of business in the educational cluster is also partnership with local authorities for the benefit of the territory's development, which the authorities can make attractive for the entrepreneurs by providing various types of assistance (administrative and marketing support, assistance in the development of cooperation, attracting investments in maintaining relations between the structures of production, processing and marketing of agricultural products, ensuring the availability of local producers of agro-food markets, the protection of entrepreneurs' rights, ensuring a competitive environment, representation of interests in higher authorities, etc.) [4].

According to the international experience, social partnership of business, community and local authorities is fundamentally significant for the cluster formation. In terms of clusters not only organizational interaction and contractual obligations are possible. A non-profit partnership involving local administration can be the legal and organizational form. It is also possible to create innovative partnerships that do not require the registration of legal entities. Taking into account the typical stages of cluster formation described in the scientific literature we have identified the following necessary steps in the process of creating educational clusters [8]:

1) identifying and justifying strategic initiatives in the sphere of education, prior for the development of the territory where a cluster should be created;

2) predicting the goal-oriented (educational), social, economic (trade and budget) efficiency of the cluster

\section{REFERENCES}

1. Chernyshova, Ye. R. (2012). Osvitni klastery yak shliakh pidvyshhennia konkurentozdatnosti navchalnykh zakladiv systemy pisliadyplomnoi pedahohichnoi osvity [Educational clusters as a way to increase the competitiveness of postgraduate educational institutions]. Kyiv: Pedagogichna dumka [in Ukrainian].

2. Korchagina, N. A. (2012). Obrazovatelnye klastery kak osnova povysheniya konkurentosposobnosti uchebnyh zavedeniy [Educational clusters as a basis of increasing educational institutions' competitiveness]. considering public and private investments and all kinds of effect (in the national, territorial and sectoral aspects);

3 ) determining the list of the cluster's members defining their roles and functions in achieving the final results of the target;

4) designing the forms of joint activities;

5) designing the structure of managing the cluster based on a combination of collective forms of decisionmaking on key parameters of joint activities and target indicators with the diversity of decentralized forms of networked horizontal interactions;

6) developing and approving the necessary normative legal base at the level of local government, regulating interaction within the frames of the cluster and encouraging its members; designing and implementing institutional support.

7) creating an information space that provides a broad public support and a favorable climate for innovations.

Based on the strategic plans of the territory development in each cluster the terms of growth are distinguished which are consistent with the priorities and can attract the resources of the partner organizations. These points of growth would be not educational institutions but new educational programs or supporting innovative integrated projects capable of engaging the partners, ensuring higher quality of education for the population, increasing social perspectives. The proposed measures contribute to the innovative development of both social sphere and a real sector of economy [9].

\section{Conclusions}

Thus, summing up the above mentioned it can be affirmed that the education cluster can be a tool of state policy of Ukraine in the field of gaining a leading position in the global markets of education. The formation and development of effective education clusters will contribute to the acceleration of the transfer (exchange) of information and networking; faster response to the changes in the environment; facilitation of the access to new technologies; knowledge and assets sharing; acceleration and improvement of the efficiency of staff training through concentration, physical contacts of world class specialists, correction of the curricula, organization of joint programs of training; transaction costs reduction in various areas; investments increasing by means of achieving sustainable competitive advantages.

Caspian magazine: management and high technology, 3 (7), 78-84 [in Russian].

3. Smirnov, A. V. (2010). Obrazovatelnye klastery $i$ innovatsionnoe obuchenie $v$ vuze [Educational clusters and innovative teaching in higher educational institution]. Kazan: RITS «Schola» [in Russian].

4. Shestakovska, T. L. (2013). Obrazovatelnye klastery kak organizatsionno-ekonomicheskaya forma realizatsii strategii razvitiya obshhego srednego obrazovaniya [Educational clusters as the organizational form 
of economic development strategy of general secondary education]. Izvestiya Gomelskogo gosudarstvennogo universiteta imeni F. Skoriny - Proceedings of Francisk Skorina Gomel State University, 2, 116-112 [in Russian].

5. Gryshova, I. Yu., \& Shabatura, T. S., \& Naumov, O. B. (2016). The capitalization of the brand as a tool for maximizing business value. Naukoviy visnik Polissya - Scientific bulletin of Polissia, 3(6), 168-175 [in Ukrainian].

6. Gryshova, I., \& Mityay O., \& Stoyanova-Koval S. (2016). The estimation of enterprise trade name competitiveness. Scientific bulletin of Polissia, 2(6), 85-91 [in Ukrainian].

\section{ЛІТЕРАТУРА}

1. Чернишова Є. Р. Освітні кластери як шлях підвищення конкурентоздатності навчальних закладів системи післядипломної педагогічної освіти / Є. Р. Чернишова. - К. : Педагогічна думка, 2012. - 72 с.

2. Корчагина Н. А. Образовательные кластеры как основа повышения конкурентоспособности учебных заведений / Н. А. Корчагина // Прикаспийский журнал: управление и высокие технологии. К., 2012. №3 (7). - С. 78-84.

3. Смирнов А. В. Образовательные кластеры и инновационное обучение в вузе: монография / А. В. Смирнов. - Казань: РИЦ «Школа», 2010. - 102 с.

4. Шестаковська Т. Л. Образовательные кластеры как организационно-экономическая форма реализации стратегии развития общего среднего образования / Т. Л. Шестаковская // Известия Гомельского государственного университета имени Ф. Скорины. 2013. - №2(77). - C.116-122.

5. Гришова I. Ю. Капіталізація бренду як інструмент максимізації ринкової вартості бізнесу
7. Gryshova, I. Yu., \& Strielkowski, W. (2016). Ukrainian labour migration in the Czech Republic. Scientific bulletin of Polissia, 3 (8), 224-231 [in Ukrainian].

8. Shestakovska, T. L., \& Savchenko V.F. (2016). Osoblyvosti formuvannia sotsialno orientovanykh klasteriv v Ukraini [Features of formation of socially oriented clusters in Ukraine]. Naukovyi visnyk Polissia - Scientific bulletin of Polissia, 1, 46-55 [in Ukrainian].

9. Naymova, L. N., \& Mityay, O. V., \& Galitsky, A. N. (2016). Development of the innovative enterprises of the agrarian production in the current economic system of Ukraine. Scientific bulletin of Polissia, 3 (7), 124-129 [in Ukrainian].

/ І. Ю. Гришова, Т. С. Шабатура, О. Б. Наумов // Науковий вісник Полісся. - 2016. - №3(6). - С. 168-175.

6. Gryshova I. Yu. The estimation of enterprise trade name competitiveness / I. Yu. Gryshova, O. Mityay, S. Stoyanova-Koval // Scientific bulletin of Polissia. 2016. - №2(6). - C 85-91.

7. Gryshova I. Yu. Ukrainian labour migration in the Czech Republic / Wadim Strielkowski, I. Yu. Gryshova // Scientific bulletin of Polissia. - 2016. - №4(8). - C.224231.

8. Шестаковська Т. Л. Особливості формування соціально орієнтованих кластерів в Україні / В. Ф. Савченко, Т. Л. Шестаковська // Науковий вісник Полісся. - 2016. - №1. - С.46-55.

9. Naymova L. N., Mityay O. V., Galitsky A. N. Development of the innovative enterprises of the agrarian production in the current economic system of Ukraine / L. N. Naymova, O. V. Mityay, A. N. Galitsky// Scientific bulletin of Polissia. - 2016. - №3 (7). - P.124-129

Інна Юрї̈на Гришова, доктор економічних наук, дочент, головний науковий співробітник Інституту законодавства Верховної Ради Украӥни, пров. Несторівський, 4, м. Київ, Украӥна,

Віктор Анатолійович Замлинський, доктор економічних наук, доцент кафедри обліку і оподаткування Одеський торгівельно-економічний інститут Київського національного торгівельно-економічного університету вул. 25 Чапаӥвської дивізї, 7, м. Одеса, Украӥна,

Тетяна Леонідівна Шестаковська,

кандидат економічних наук, старший викладач кафедри економічної теорії, Чернігівський національний технологічний університет, Міністерство освіти і науки Украӥни, вул. Стрілецька, 1, м. Чернігів, Україна

\section{ІМПЛЕМЕНТАЦІЯ КЛАСТЕРНИХ ФОРМ У СТРАТЕГІЮ РОЗВИТКУ ВІТЧИЗНЯНОЇ ОСВІТИ}

Реалізація принципів функціонування сучасної освіти може здійснюватися тільки в інноваційному середовищі, яке передбачає імплементацію кластерних форм в організації процесів взаємодії під час навчання. Метою дослідження є визначення доцільності використання кластерного підходу у процесах управління стратегічним розвитком вітчизняної системи освіти в ринкових умовах на основі теоретичних методів. У статті розглядаються особливості формування освітніх кластерів як однієї із форм розвитку системи вітчизняної освіти. Удосконалено сутність поняття «освітній кластер» шляхом виокремлення необхідних етапів та засобів інноваційної діяльності у тій його частині, яка відповідає за створення нових освітніх систем або їх окремих компонентів. Освітній кластер у до- 
слідженні інтерпретується як сукупність організацій різної галузевої приналежності та організаційно-правових форм, владних і громадських структур, що визначають та забезпечують реалізацію освітніх програм певного рівня чи спрямованості, а також умови для стратегічного інноваційного розвитку системи освіти в сучасних ринкових умовах із залученням специфічних форм організації інноваційної діяльності, які зарекомендували себе в процесі реалізації широкомасштабних експериментів, пілотних проектів з окремих напрямків модернізації. Описано можливості впровадження освітніх кластерів на різних управлінських рівнях. Запропоновано структуру освітнього кластеру, а також конкретні етапи його впровадження. Обгрунтовано результати ефективної реалізації освітніх кластерів у напрямку стратегічного розвитку вітчизняної системи освіти. Освітній кластер може виступати інструментом державної політики України в сфері завоювання провідних місць на світових ринках освітніх послуг. Формування та розвиток ефективних освітніх кластерів сприятиме: прискоренню передачі (обміну) інформації і встановлення контактів, реакції на зміни в зовнішньому середовищі; спрощенню доступу до нових технологій; спільному використанню знань $\mathrm{i}$ основних фондів; прискоренню і підвищенню ефективності процесів навчання та професійної підготовки кадрів за рахунок концентрації, фізичних контактів фахівців високого рівня, корегування навчальних планів закладів освіти, спільної організації програм перепідготовки та підвищення кваліфікації кадрів, стажувань; зниженню трансакційних витрат у різних областях; збільшенню інвестицій завдяки досягненню стійких конкурентних переваг.

Ключові слова: освітній кластер, управління освітою, партнерство, інновації, ефективність кластерів, стратегічний розвиток освіти.

Submitted on April, 14, 2017

UDC:373.5.091.33:62

DOI: https://doi.org/10.24195/2414-4665-2017-5-12

Liudmyla Chystiakova,

PhD (Candidate of Pedagogical Sciences), associate professor, Department of Theory and Methodology of Technological Education, Labour Protection and Health, Volodymyr Vynnychenko Central Ukrainian State Pedagogical University,

1, Shevchenko Str., Kropyvnytskyi, Ukraine

\section{THE PROJECT METHOD AT DESIGN AND TECHNOLOGY LESSONS IN TERMS OF REFORMING THE NEW UKRAINIAN SCHOOL}

According to a new program for general secondary education institutions approved by the Ministry of Education and Science of Ukraine, Design and Technology Lessons are considered as a leading tool of the development of students' ability for self-studying, mastering the tools of modern technologies, building the cognitive process and carrying out their plans practically. Labour training provides the formation, purposeful manifestation and development of students' skills and cultivates their project and technological competency as a component of key and subject competencies. The aim of the paper is to provide explanation of the efficiency of the project method and the necessity of its implementation during academic and labour training at Design and Technology lessons. The survey results of Design and Technology teachers from different regions of Kirovohrad region have shown that most of them do not have profound knowledge of using the project method in their teaching practice. They are not quite aware of the requirements of projects and main tasks of the project-based teaching technology, that is why the study is considered to be relevant for Ukrainian education system. The use of the project method in the art and labour creativity will enhance a holistic development of students' personalities, their preparation for the subjecttransforming activity. It also helps students to satisfy their own interests, needs; cultivate their independence, develop their communicative skills. The purpose of an academic project is to create such educational conditions under which students will gain the experience in a project activity. The project based technology covers the following issues: didactic, educational, developmental. Some recommendations for teachers working with this technology have been also presented in the paper.

Keywords: the project method, labour training, the project based technology, a project and technological competency, a creative activity

\section{Introduction}

Labour training classes which students attend at general secondary education institutions are aimed at shaping a new kind of personality who knows how to use methods of a creative search, manifests a creative initiative, is aware of the priority of choosing the right tools in order to achieve the ultimate goal, possesses technological knowledge and has a vision of creative orientation of his/her activity. Labour training should be intellectually coloured. It should provide holistic and all-round education helping every student to develop physically, intellectually, socially and spiritually by implementing a person- 